alleged economic and technical advantages (not always clearly stated) of the advanced gas-cooled reactor. Granted that the book cannot possibly include everything there are, nevertheless, some astonishing omissions: concrete pressure vessels, for example, are dismissed in a few lines. Units are not always in accordance with modern definitions. Technological data are often sparse. All this tends to strengthen a feeling that the volume has been a long time in preparation and perhaps by authors who in some cases were past the first wave of enthusiasm that writing up a new subject can give. Throughout the book there are few diagrams and these are not generally of high quality. Rather surprisingly one has to turn as far as p. 339 before finding a diagram of a power reactor and, in a 50-page chapter on fuel elements, there is only one, inadequate sketch of a helical polyzonal fuel element can.

In conclusion, one feels that this book is less likely to be of use to the postgraduate student or newcomer to the nuclear field than to the engineer already engaged in gascooled reactor technology who requires a first reference book to parts of the subject in which he is not already a specialist.

C. P. HaIgh

\section{MEAT FOR THE HUNGRY}

\section{The Better Use of the World's Fauna for Food}

Edited by J. D. Ovington. (Symposia of the Institute of Biology, No. 11.) Pp. xi +175 . (London: The Institute of Biology, 1963.) 25s.

$\mathrm{M}$ UCH credit is due to the Institute of Biology for organizing its important symposium on "The Better Use of the World's Fauna for Food" and for publishing the proceedings. This is especially so at a time when so much interest is being taken in possible methods of meeting the growing menace of malnutrition in the emergent countries, particularly in those where the annual increase (if any) in the production of protein foods lags ever farther behind the inordinate increase in popula. tion. The book contains the fifteen papers that were delivered at the four sessions of the two-day symposium, and are all from speakers with recent first-hand acquaintance with the topics they discuss.

'The first paper deals with the assessment of the world's protein needs and supplies, pointing out the difficulty of obtaining reliable quantitative data for food consumption in socially under-developed countries. The value of clinical and other direct observations of serious malnourishment is emphasized. In the second paper, the question is ably discussed of the relative merits of plant and animal protein in human dietaries.

These introductory papers are followed by a number of diverse contributions on such subjects as the potentialities of animal husbandry in West Africa; new developments in 'game-cropping' in the same continent; the saiga antelope in the semi-desert and steppe regions of the U.S.S.R. as a source of food; and the methods of processing and preserving meat in less-developed areas. An odd but interesting account is given of the extensive use in parts of West Africa of the giant African snail-rich in protein-as a dietary supplement. It is pointed out that in many countries where snails are a pest it would be doubly advantageous to eat them. Several papors deal with the progress that has been, and the further progress that might be, made in both marine and inland fishories, including fish cultivation in freshwater ponds (an enterprise now extending in many of the less-developed areas, but requiring, in some districts, anti-malarial pre(autions).

In many maritime tropical countries, sea fisheries, with improved methods and gear, are capable of adding much valuable protein to human diet; culture of shell 'fish' in different parts of the world gives promise for another such addition. A final paper, short but fascinating, and leading to a lively discussion emphasizes the challenge to marine biologists of the urgent need for increasing the world's fish harvest by "farming the seas". While much knowledge is already available, far more is needed to improve the growth of plankton, for example, or to control certain competitors for the food which should go to edible fish. The need for realizing the potential of marine fisheries is no less a challenge to international co-operation.

It would be a rewarding use of their time if those diresting nutritional policy in developing countries were to read this fresh and stimulating book. It should be of no less value to all concerned with the Freedom from Hunger Campaign.

H. D. KAY

\section{TROPICAL FLORAS IN THE TERTIARY OF SOUTHERN ENGLAND}

\section{The Lower Tertiary Floras of Southern England}

3: Flora of the Bournemouth Beds: The Boscombe and the Highcliff Sands. By Marjorie Elizabeth Jano Chandler. Pp. xi $+169+25$ plates. (London: British Museum (Natural History), 1963.) $210 s$.

HIS completes tho series of three important monographs on the Lower Tertiary floras of southorn England by Miss Chandler published by the British Museum. Volume 1 was reviewed in 1961 (Nature, 195 , 209) and Volume 2 in 1962 (Nature, 198, 47). The third deals with the Flora of the Bournemouth Beds: The Bos. combe and the Highcliff Sands.

The Bournemouth Freshwater Beds are shown by Miss Chandler to contain the remains of a rich flora and are purely continental deposits. They differ mainly from the Dorset Pipe-clay Series, which they succeed, in having only sparse pipe-clay strata but considerable thicknesses of grits, marls, fine clays and silts. In Volume 1, Miss Chandler gave two alternative correlations between these freshwater beds and the corresponding European stages. Arkell had included all the freshwater beds above the London Clay up to the top of the Bournemouth Freshwater Beds to the Cuisian while Wrigley and Davis had previously attributed the Lower Bagshot Beds to the Cuisian and the Bournemouth Freshwater Beds to the Lutetian. Miss Chandler follows Wrigley and Davis in treating the flora of the Bournemouth Beds soparately from that of the Dorset Pipe-clays.

The Bournemouth Beds have yielded the remains of a flora of ferns, conifers, and angiosperms indicating a tropical or sub-tropical climate. These deposits aro succeeded by the Bournemouth Marine Beds and then by the Boscombe and Highcliff Sands. There is no indication from the available evidence of any approciable floristic or elimatic change during the periods of deposition of the sediments examined in this work. Miss Chandler remarks that although the flora of the Pipe-clay Sories appears to be more tropical than that of the Bournemouth flora this is probably due to the greater number of fossils discovered in the former. She also suggests that the evidence is in favour of the view that in the Eocene there was a belt of uniform tropical vegetation around the equatorial regions of the world and that, later, areas of this became separated and differentiation of species and genera occurred in its various parts.

In these three volumes she has made an outstanding contribution to the knowledge of Tertiary floras which will be of great value to those interested in the evolution of existing floras. Again, her deseriptions and illustrations, including more than 800 reproductions of photographs of fossils, are of first-rate quality.

Miss Chandler hopes before long to prepare an account of the main conclusions arising from her investigations. To this we look forward eagerly. J. WALTON 